\title{
Social, Academic Performance among Internet Use and Its Impacts on University Students: A Case Study in Bangabandhu Sheikh Mujibur Rahman Science and Technology University
}

Ali Hossain*, Md. Mahbub Arifin, Salman Ahammed and Md. Tofazzal Hossain

Department of Statistics, Bangabandhu Sheikh Mujibur Rahman Science and Technology University, Gopalganj, Bangladesh

\begin{abstract}
Internet has become the important part of everyone's life. Large numbers of students spend a lion share of daily time by using internet. So it was imperative to mention the effects of using internet on the society. The main aim of this study was to analyze whether the use of internet can influence student's academic results or not. To get the desired answer, a simple random sample constituted with 150 students in Bangabandhu Sheikh Mujibur Rahman Science and Technology University, Gopalganj-8100, was drawn and surveyed questionnaire. This study significantly found that student's average results were inversely influenced by their hours of regular involvement of internet. Based on the findings, this study concludes that students' involvement in internet in terms of hours should be closely monitored to overcome this inverse effect.
\end{abstract}

Keywords: Social; Humanity; Internet; Significance; Regression model

\section{Introduction}

The internet is a global network connecting millions of peoples. More than 190 countries are linked into exchanges of data, news and opinions. According to internet live stats, as of August 07, 2015 there was an estimated 3,179,035,200 internet users worldwide. The number of internet users represent nearly 40 percent of the world's population. China is the largest internet users, followed by United States and India. According to internet live stats, as of July 01, 2016 there was an estimated 21,439,070 internet users in Bangladesh (www. internetlivestats.com). Generally human beings connect with each other via internet and do their necessary works like gossiping, shopping and many other social and academic tasks. Now, academic and social life is dependent partially and/or fully on the internet. It is mediating and transforming a variety of activities in the society of human being in the areas of politics, religion and language.

Previous researchers have significantly analyzed and documented different aspects internet use in Bangladesh. Kabir, et al. analyzed Exploitation of social networking sites and its impacts on students' academic results [1]: A quest for correlation or misspecification in Bangladesh; Lane has conducted a case study for the GSM association; Roknuzzaman has conducted a survey on internet access in large public university [2]; Islam and Hossain has studied access and use of internet among under graduate students in the faculty of arts, university of Dhaka, Bangladesh [3]; Azam has studied the internet adoption and its usage [4]; Mostofa has studied the access and use of internet among business students of a private university of Bangladesh. But none of them have investigated the impacts of the use of internet among university students academic result in Bangladesh.

This study primarily attempts to identify whether the use of internet by university students has any tendency to influence their academic results or not. Also identify purpose of using internet; average hour spending on internet $[5,6]$. Higher education is a key component of a country and remaining globally competitive and declining academic performance can have long-term consequences for both society and the individual in terms of overall quality of life.

\section{Objectives}

1. To find out purpose of using internet among university students.

2. To find out average hour spending on internet per day.

3. The main objective was to identify whether the use internet by university students has any tendency to influence their academic results or not.

\section{Methods and Materials}

\section{Data collection}

In this study, primary type of data was used the data were obtained from Bangabandhu Sheikh Mujibur Rahman Science and Technology University campus.

\section{Sampling technique and sample size}

The sample of the present study was drawn from students (those who have completed at least two semesters with their results published). The sample consisted 150 students in Bangabandhu Sheikh Mujibur Rahman Science and Technology University, Gopalganj-8100. Out of 150 students 100 male and 50 female. For selection of sample simple random sampling technique had been adopted.

\section{Results and Discussion}

\section{Internet use}

One hundred fifty students participate in this study.

*Corresponding author: Ali Hossain, Department of Statistics, Bangabandhu Sheikh Mujibur Rahman Science and Technology University, Gopalganj, Bangladesh, Tel: +880-02-6682257; E-mail: alistat31@gmail.com

Received September 26, 2018; Accepted October 10, 2018; Published October 17, 2018

Citation: Hossain A, Arifin M, Ahammed S, Hossain T (2018) Social, Academic Performance among Internet Use and Its Impacts on University Students: A Case Study in Bangabandhu Sheikh Mujibur Rahman Science and Technology University. Arts Social Sci J 9: 411. doi: 10.4172/2151-6200.1000411

Copyright: @ 2018 Hossain A, et al. This is an open-access article distributed under the terms of the Creative Commons Attribution License, which permits unrestricted use, distribution, and reproduction in any medium, provided the original author and source are credited. 
Citation: Hossain A, Arifin M, Ahammed S, Hossain T (2018) Social, Academic Performance among Internet Use and Its Impacts on University Students: A Case Study in Bangabandhu Sheikh Mujibur Rahman Science and Technology University. Arts Social Sci J 9: 411. doi: 10.4172/2151-6200.1000411

Page 2 of 3

In Figure 1 we see that out of 150 students, 146 (97.3\%) students use internet. Only $4(2.7 \%)$ students never use the internet. This proportion (2.7\%) may look minimal and suggests over-whelming accessibility of the respondents to internet facilities.

\section{Frequency of using internet}

Figure 2 shows that the frequency of using internet by Bangabandhu Sheikh Mujibur Rahman Science and technology university students. It has been observed that 105 students are used daily, 12 are used twice a week, 17 are used weekly, 3 are used monthly and 9 are used rarely $[7,8]$.

Internet is one of the most important and powerful means for information retrieval and dissemination. It helps students/researchers in collecting the right information at a right time easily and also updates their knowledge. So they use internet daily.

\section{Purpose of using internet}

Internet use has both advantages and disadvantages. It depends upon the purpose of use. If it is purposely used, it helps to increase knowledge and keeps oneself abreast of the latest developments. From Figure 3 we see that most of the respondents (50 out of 150) using internet for study, Recreation or relaxation and using social networking site (Figure 3, Tables 1 and 2).

\section{Hypothesis}

$\mathrm{H}_{0}$ : There is no relationship between average hour spending on internet per day and C.G.P.A.

$\mathrm{H}_{1}$ : There is relationship between average hour spending on internet per day and C.G.P.A.

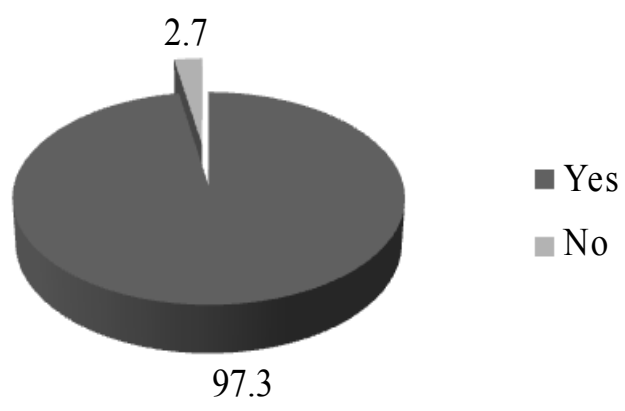

Figure 1: Pie chart of internet use of respondent.

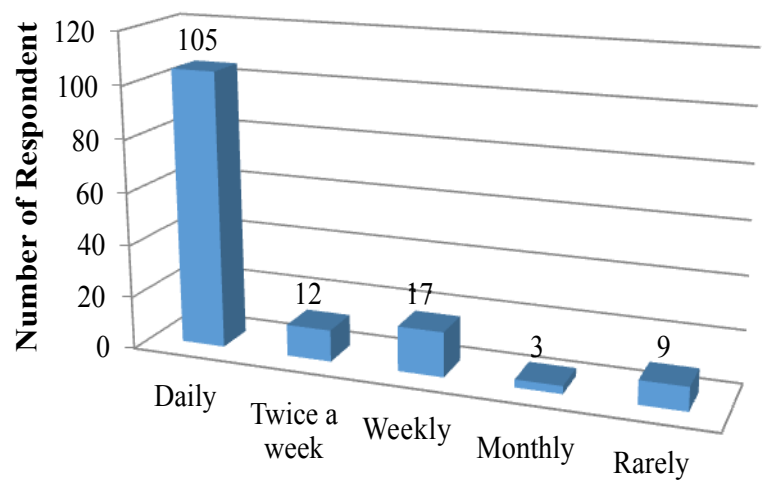

Figure 2: Frequency of using internet.

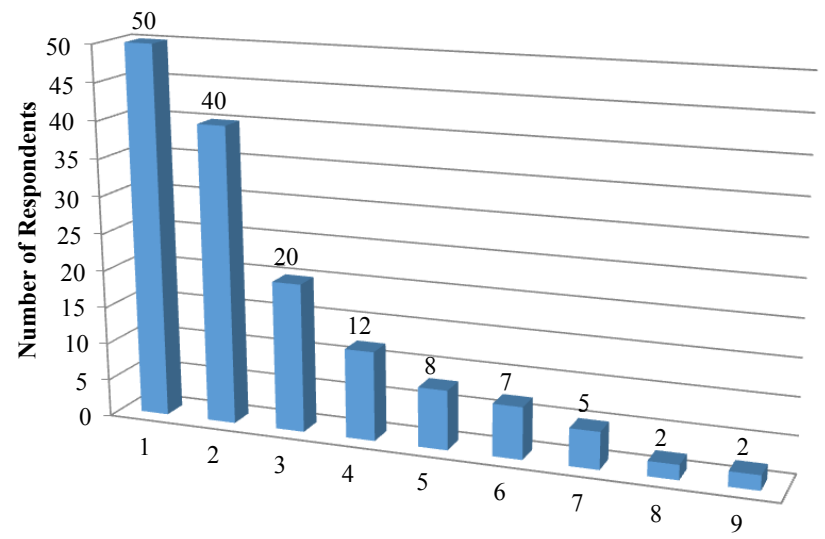

Figure 3: Purpose of using internet. Note: $1=$ Study, Recreation or relaxation and using social networking site, 2=Recreation or relaxation, 3=Downloading music or video, 4=Onlinegames, $5=$ Reading newspaper and magazine, $6=$ Using social networking site, $7=$ Email, $8=$ Chatting, $9=$ others.

\begin{tabular}{|c|c|c|c|c|c|c|}
\hline \multirow{2}{*}{\multicolumn{2}{|c|}{$\begin{array}{c}\text { Average hour } \\
\text { spending on internet } \\
\text { per day }\end{array}$}} & \multicolumn{4}{|c|}{ C.G.P.A } & \multirow{3}{*}{$\begin{array}{r}\text { Total } \\
89 \\
\end{array}$} \\
\hline & & \multirow{2}{*}{$\begin{array}{c}\text { Less than } \\
3.25 \\
22 \\
\end{array}$} & \multirow{2}{*}{\begin{tabular}{|c|}
$3.25-3.50$ \\
24 \\
\end{tabular}} & \multirow{2}{*}{\begin{tabular}{|c|}
$3.50-3.75$ \\
30
\end{tabular}} & \multirow{2}{*}{$\begin{array}{c}\text { More than } \\
3.75 \\
13 \\
\end{array}$} & \\
\hline Less than 2 & Obs. & & & & & \\
\hline hour & Exp. & 31.7 & 23.2 & 25.0 & 9.1 & 89 \\
\hline \multirow[t]{2}{*}{ 2-3 hour } & Obs. & 11 & 5 & 8 & 1 & 25 \\
\hline & Exp. & 8.9 & 6.5 & 7.0 & 2.6 & 25 \\
\hline \multirow[t]{2}{*}{ 3-4 hour } & Obs. & 8 & 1 & 2 & 1 & 12 \\
\hline & Exp. & 4.3 & 3.1 & 3.4 & 1.2 & 12 \\
\hline \multirow{2}{*}{$\begin{array}{l}\text { More than } 4 \\
\text { hour }\end{array}$} & Obs. & 11 & 7 & 1 & 1 & 20 \\
\hline & Exp. & 7.1 & 5.2 & 5.6 & 2.1 & 20 \\
\hline \multirow[t]{2}{*}{ Total } & Obs. & 52 & 38 & 41 & 15 & 146 \\
\hline & Exp. & 52.0 & 38.0 & 41.0 & 15.0 & 146 \\
\hline
\end{tabular}

Table 1: Cross tabulation between average hour spending on internet per day and academic results (C.G.P.A).

\begin{tabular}{|c|c|c|c|c|}
\hline Chi-Square Tests & Value & df & $\begin{array}{c}\text { Asymp. Sig } \\
\text { (2-sided) }\end{array}$ & $\begin{array}{c}\text { Exact. Sig } \\
\text { (2-sided) }\end{array}$ \\
\hline Pearson Chi-square & $19.699(\mathrm{a})$ & 9 & 0.02 & 0.019 \\
\hline Likelihood Ratio & 21.924 & 9 & 0.009 & 0.015 \\
\hline Fisher's Exact test & 19.158 & & & 0.015 \\
\hline $\begin{array}{c}\text { Linear by Linear } \\
\text { Association }\end{array}$ & $14.159(\mathrm{~b})$ & 1 & 0 & 0 \\
\hline
\end{tabular}

Table 2: Hypothesis.

From the cross table we see that all cell frequency is not greater than 5 so we consider Likelihood Ratio test. From Likelihood Ratio test, at $5 \%$ level of significant with 9 degrees of freedom, the calculated value is 21.924 which significant level is 0.009 which is less than 0.05 . Hence we reject null hypothesis $\left(\mathrm{H}_{0}\right)$. That is there is significant association between average hour spending on internet per day and C.G.P.A (Table 2).

\section{Dummy variable regression model}

Average hour spending on internet per day is defined on following category:

Defined categories with average hour spending on internet per day is given below:

Low use: Less than 2 hour,

Low medium use: 2-3 hour, 
Citation: Hossain A, Arifin M, Ahammed S, Hossain T (2018) Social, Academic Performance among Internet Use and Its Impacts on University Students: A Case Study in Bangabandhu Sheikh Mujibur Rahman Science and Technology University. Arts Social Sci J 9: 411. doi: 10.4172/2151-6200.1000411

Page 3 of 3

Medium use: 3-4 hour

Heavy use: More than 4 hour.

Dummy variable regression model of average hour spending on internet per day on results (C.G.P.A).

Let,

$\mathrm{Y}_{\mathrm{i}}=$ Results (C.G.P.A)

$\mathrm{D}_{2 \mathrm{i}}=1$ Heavy use

$=0$ Otherwise

$\mathrm{D}_{3 \mathrm{i}}=1$ Medium use

$=0$ Otherwise

$\mathrm{D}_{4 \mathrm{i}}=1$ Low medium use

$=0$ Otherwise

Here, the benchmark/reference category is low use.

Now the dummy variable regression model is

$Y_{i}=\beta_{1}+\beta_{2} D_{2 i}+\beta_{3} D_{3 i}+\beta_{4} D_{4 i}+u_{i}$

$\beta_{1}, \beta_{2}, \beta_{3}$ and $\beta_{4}$ are regression coefficients (Table 3).

a. Dependent variable: Results (C.G.P.A).

Comment: The coefficients $\beta_{1}, \beta_{2}$ and $\beta_{3}$ are statistically significant. The average result of the respondents who use internet low (less than 2 hour) is about 3.44 .

The average result of the respondents who use internet heavy (more than 4 hour) is lower by about 0.313 than the respondents who use internet low (less than 2 hour) (Table 4).

The average result of the respondents who use internet medium (3-4 hours) is lower by about 0.235 than the respondents who use internet low (less than 2 hour).

\section{Predicting average results (C.G.P.A) using logistic regression model}

From Table 4 it is observed that all the predictors have significant

\begin{tabular}{|l|c|c|c|c|c|}
\hline Predictors & Coefficients $\boldsymbol{\beta}$ & Std. Err. & t-test & $\mathbf{p}$-value & $\mathbf{9 5 \%}$ CI for $\boldsymbol{\beta}$ \\
\hline Constant & 3.440 & & 10.401 & 0.000 & 3.374 to 3.506 \\
\hline Heavy use & -0.313 & 0.078 & -4.024 & 0.000 & -0.466 to -0.159 \\
\hline Medium use & -0.235 & 0.097 & -2.435 & 0.016 & -0.426 to -0.044 \\
\hline Low medium use & -0.099 & 0.071 & -1.396 & 0.165 & -0.240 to .041 \\
\hline
\end{tabular}

Table 3: Results of dummy variable regression model.

\begin{tabular}{|c|c|c|c|c|c|}
\hline Predictors & $\begin{array}{l}\text { Odds } \\
\text { Ratio }\end{array}$ & Std. Err. & z-test & p-value & $\begin{array}{c}95 \% \mathrm{Cl} \text { for } \\
\text { OR }\end{array}$ \\
\hline \multicolumn{6}{|c|}{ Average hour spending on internet per day } \\
\hline Less than 2 hour & Reference & & & & \\
\hline More than 2 hour & 0.39 & 0.389 & -2.422 & 0.015 & $0.182-0.836$ \\
\hline \multicolumn{6}{|c|}{ Average hour spending on Facebook, Whatsapp, Twitter per day } \\
\hline Less than 2 hour & Reference & & & & \\
\hline More than 2 hour & 0.322 & 0.459 & -2.470 & 0.014 & $0.131-0.791$ \\
\hline
\end{tabular}

effect on response variable (Results C.G.P.A). Student with average hour spending on internet per day more than 2 hours are $61 \%$ less likely to have results (C.G.P.A) more than 3.25 than those with average hour spending on internet per day less than 2 hour. Student with average hour spending on Facebook, Whats app, Twitter per day more than 2 hours are $68 \%$ less likely to have more than results (C.G.P.A) 3.25 than those with averages of internet per day less than 2 hour.

\section{Conclusion}

According to analysis in Bangabandhu Sheikh Mujibur Rahman Science and Technology University, we have seen that most of the students $(97.3 \%)$ used internet. We found that main purpose of using internet for study, recreation or relaxation and using social networking site. As consequences, it had significantly been found in this study that, university student's academic results were inversely influenced by the use of internet. That was the students who spend more time on internet per day, their result was lower. It had been suggested based on the findings that time spending on internet must be closely monitored by their parents and teachers for upgrading academic results.

\section{References}

1. Kabir T, Akter S, Ferdus Z (2014) Exploitation of social networking sites and its impacts on students' academic result: A quest for correlation or misspecification. Journal of business and technology 9: 1 .

2. Roknuzzaman M (2006) A survey of internet access in a large public university in Bangladesh. International Journal of education and development using information and communication technology (IJEDICT) 2: 86-105.

3. Anwarul IM, Muhammad JH (2012) Access and use of the internet among undergraduate students in the faculty of arts, University of Dhaka, Bangladesh. Pakistan Journal of Library and Information Science.

4. Azam MS (2007) Internet adoption and usage in Bangladesh, Japanese Journal of Administrative science 20: 43-54.

5. Chongtham BD, Nil RR (2012) Internet use among university students: A case study of Assam University, Silchar.

6. Haque MA (2015) Social and academic use of internet by the graduate students in Finland and Bangladesh: A comparative study.

7. Anderson K (2001) Internet use among college students: Should be concerned? Paper presented at the American psychological association, Boston, M.A.

8. Internet World Stats. 